\title{
A stalled revolution? Gender role attitudes in Australia, 1986-2005
}

\author{
Marcel van Egmond • Janeen Baxter • \\ Sandra Buchler • Mark Western
}

Published online: 26 October 2010

(C) The Author(s) 2010. This article is published with open access at Springerlink.com

\begin{abstract}
This paper examines trends over time in attitudes to gender equality in Australia. We use data from repeated cross-sectional surveys in Australia to investigate trends in beliefs about men's and women's work and family roles between 1986 and 2005. We find that men are consistently more conservative than women, that younger cohorts tend to be less conservative than older cohorts, but those born between 1960 and 1980 are more egalitarian on some issues than those born after 1980. There is also evidence that the overall trend toward more egalitarian gender attitudes is most marked in Australia up until the mid-1990s with the trend flattening and in some cases, even reversing after this period. The paper concludes that there is currently a period of relative stability in gender attitudes in Australia, but with some tendency toward more conservative views.
\end{abstract}

Keywords Gender attitudes · Gender roles · Male breadwinner - Change over time

\section{Introduction}

There is substantial evidence in support of trends toward more egalitarian beliefs about men's and women's work and family roles across the Western world since the 1960s (Brewster and Padavic 2000; Inglehart and Norris 2003; Scott 2008; Thornton

\footnotetext{
M. van Egmond

Department of Communication Science, University of Amsterdam, Kloveniersburgwal 48, 1012 CX Amsterdam, The Netherlands

J. Baxter $(\bowtie) \cdot$ S. Buchler

School of Social Science, The University of Queensland, St. Lucia, QLD 4072, Australia

e-mail: j.baxter@uq.edu.au

J. Baxter · M. Western

Institute for Social Science Research, The University of Queensland, St. Lucia, QLD, Australia
} 
and Young-DeMarco 2001). In addition to numerous studies documenting these attitudinal shifts, evidence is also provided by legislative changes such as equality of opportunity and sex discrimination legislation, and women's increased access to and participation in higher education and paid employment. Additionally we have seen marked changes in the patterning of relationships, marriage, divorce and fertility patterns, all of which imply a shift in beliefs about appropriate behaviour for men and women. These changes suggest that compared to previous generations, men and women now hold more egalitarian beliefs about gender behaviour.

But there is also evidence that trends toward more egalitarian views have slowed or even reversed in recent years: some commentators report a backlash in public opinions about feminism (Faludi 1992; Holtz 1995) and survey data on gender role attitudes show a flattening of trends (Brewster and Padavic 2000; Inglehart and Norris 2003; Scott 2008).

There are a number of reasons why this may have occurred. One possibility is that attitudes changed rapidly throughout the 1970s and 1980s as a result of second wave feminism and the influx of married women into the labour market, but may have reached a point of equilibrium once the idea of women's work outside the home became less novel and trends toward dual earner households became more widespread. Another possibility is that the goal of gender equality may have proved more elusive and less rewarding than originally anticipated by women in the 1970s, resulting in a tempering of ideas about appropriate gender roles. Still another possibility is that as fertility rates have declined and the population has aged, any observed slowdown in trends toward egalitarian attitudes is simply an artefact of the ageing of the population.

This paper investigates trends in gender role attitudes for Australian men and women for the period 1986-2005. During this time women's labour force participation rate in Australia rose from 48 to $58 \%$, the proportion of women with a Bachelor degree rose from 5 to $25 \%$, and a number of important laws were passed including the Affirmative Action Act (Equal Employment Opportunity for Women) in 1986 (Australian Bureau of Statistics 2008). However, most of the growth in women's labour force participation during this period was in part-time employment, particularly casual employment (Campbell et al. 2009; van Gellecum et al. 2008), and it was during this period, in 1996, that a conservative federal government was elected with a number of policies broadly supportive of male breadwinner families. Australia ranks second only to the Netherlands in the percentage of employees in part-time employment at $24.1 \%$ of all Australian employees, and well above the OECD average of $15.3 \%$ (OECD 2009). But as in other countries, there are marked gender disparities in the distribution of part-time employment with the rate for women at $38.5 \%$, compared to $12.4 \%$ for men (OECD 2009).

We examine change over time in men's and women's levels of support for specific attitude items to investigate whether the extent of change varies depending on the behaviour in question. Previous studies have suggested that attitudinal change proceeds at different paces depending on the issue under examination, implying that the move toward more egalitarian gender beliefs has proceeded more rapidly in relation to some issues than others (Kane and Sanchez 1994; Scott 2008). Trends in women's overall labour force participation rates suggest that many people support 
women's increased access to the labour market. However, the slow pace of change in men's involvement in domestic and caring work (Baxter 2002; Bittman et al. 2003; Craig 2007) suggests that these views co-exist with traditional views about caring responsibilities in the home. Some previous research suggests growing support for the legitimacy of women's employment outside the home, but less support for the view that fathers should take equal responsibility for the care of young children (Evans and Kelley 2002; Kane and Sanchez 1994), but results are not consistent across surveys (see Braun and Scott 2009, p. 366). We also investigate how variations in individual characteristics are associated with gender beliefs to examine the factors shaping gender attitude beliefs and provide insight into why attitudes change over time.

\section{Previous research}

Previous research on trends and determinants of gender attitudes has identified a number of consistent results. First there is evidence that women hold more liberal gender attitudes than men (Brewster and Padavic 2000; Ciabattari 2001; Davis and Robinson 1991; Kane and Sanchez 1994; Scott 2008). Moreover, US evidence suggests that men's attitudes have been slower to change than women's with the result that the gap between men's and women's attitudes has widened over the last 25 years (Brewster and Padavic 2000; Ciabattari 2001). Second, there is evidence that certain key social characteristics relating to employment, family status and demographic characteristics are closely related to gender attitudes. Never-married, younger people and those with higher levels of education tend to hold more liberal attitudes than married persons and older generations or those with lower levels of education (Brewster and Padavic 2000; Davis and Robinson 1991; Thornton et al.1983). There is also evidence that women in employment hold more egalitarian attitudes than women not in employment (Scott et al. 1996). Third, there is strong evidence that gender attitudes became steadily more liberal from the 1960s to the mid-1990s, although there is some variation in results in relation to particular issues and also some suggestion that the trends may have slowed or even reversed in recent years (Brewster and Padavic 2000).

In Australia there is little research on changing attitudes to gender roles over time, but what is available tends to support international trends of increasing egalitarianism. The lack of data in Australia means that we cannot assess trends in gender role attitudes before the 1980s, but research examining trends since the mid-1980s supports the UK and US findings of increasingly egalitarian views. Evans and Kelley (2002) analyse data from the International Social Survey Program (ISSP) between 1984 and 2001 and report increasing support for women's employment outside the home, although they note that there was already considerable support for women's employment in 1984. For example, in 1984 62\% of Australians supported the statement: 'I approve of a married woman earning money in business and industry, even if she has a husband capable of supporting her', compared to $82 \%$ in 2001 . At the same time, responses to other items did not show much change; for example, $49 \%$ of respondents disagreed with the statement 'A woman should devote almost all of her time to her family' in 1984 compared to $48 \%$ who disagreed in 2001. 
Attitudes to women's employment appear to vary according to whether it is likely to affect young children. In 1985 about half of Australian ISSP respondents reported agreement with the statement 'A pre-school child is likely to suffer if their mother works'. This figure did not change substantially between 1984 and 2001. Evidence from the Australian Surveys of Social Attitudes in 2003 and 2005 further supports the view that both men and women are cautious about women's employment if it interferes with their role as carers of young children (Mitchell 2005; Western et al. 2007a). This is supported by data from other countries showing greater acceptance of women's involvement in paid labour than of altering the domestic division of labour (Kane and Sanchez 1994).

How do we explain variations over time in gender attitudes? Two main approaches have been proposed. Cohort replacement theory argues that attitudes are formed during childhood in relation to the historical and cultural context at the time (Blunsdon and Reed 2005; Brewster and Padavic 2000; Brooks and Bolzendahl 2004). This approach suggests that attitudes tend to remain reasonably stable over the lifecourse and to shape subsequent beliefs and preferences. Change in attitudes takes place when older generations are replaced by younger generations who differ in their beliefs and values because of their exposure to historically different contexts and periods during their childhood socialization (Brooks and Bolzendahl 2004).

On the other hand, theories about micro-level or intracohort change posit that individuals change their attitudes in response to changing locations within the social structure and as a result of experiences at key life course stages. With this approach social attitudes are expected to change as individuals experience different relationships, influences and events throughout their lifetime. Research has shown that individuals with higher levels of education tend to hold more egalitarian gender attitudes than those with lower levels of education, suggesting that the experience of participating in higher education may change individual attitudes (Kane 1995). Similarly, participation in the labour force may shape women's views on gender equality because of their exposure to a wider range of social relationships and their increased financial and social independence. Finally, familial events such as the birth of a child, marriage or divorce may also change individuals' gender attitudes (Amato and Booth 1991; Morgan and Waite 1987; Kane and Sanchez 1994).

Some recent research in the United States concludes that cohort replacement is the main driver of recent gender attitude change. Using data from the General Social Survey, Brooks and Bolzendahl report that almost $60 \%$ of the change in gender attitudes between 1977 and 1998 in the United States was due to cohort replacement while only about $8 \%$ of the change was due to social structural factors (Brooks and Bolzendahl 2004, p. 128); but they also note that gender attitudes are closely related to changes in attitudes to other rights-based issues. Hence increasing support for individualism, equality of opportunity and civil libertarianism will be closely linked to increasing support for feminism and women's rights (Brooks and Bolzendahl 2004). This suggests that attitudes are not developed in isolation from views about other issues, but rather are closely intertwined with other values and form a broad-based belief system.

Brewster and Padavic (2000) on the other hand, conclude that gender attitude change is driven by both cohort replacement and intracohort change. Like Mason and $\mathrm{Lu}$ (1988) they find that intracohort change accounted for more of the change in 
gender attitudes in the US in the period 1977-1985, whereas the importance of cohort replacement has increased in the period 1985-1996. They also report a considerable slowing of change from 1985 to 1996, significant fluctuations from 1 year to the next in responses to specific issues, and that men's attitudes have been changing more slowly than women's. They conclude that change over time in attitudes to gender roles is best explained by a combination of cohort replacement and intracohort effects and that future research must consider individual determinants of gender attitudes as well as cohort differences.

We draw on these earlier studies to examine changes in gender attitudes over time in Australia. First, we provide an overview of changes over time in gender attitudes in Australia for the period 1985-2005. In doing so we consider whether the observed changes over time are continuous, or whether there is evidence of a slowdown or reversal in gender attitudes as has been found in other countries. We differentiate between trends in men's and women's gender attitudes and we separately examine a number of gender attitude items since previous research has shown that attitudes vary across gender and according to the issue under examination. Second, we examine the importance of a number of demographic and social characteristics such as birth cohort, marital status, parental status, education, religiosity and employment status to investigate whether variations in these characteristics influence gender attitudes.

\section{Data}

We use data from five cross-sectional Australian surveys from 1986 to 2005 (see Appendix Table 4). Although the surveys used different methods and in some cases differing sample parameters, all are broadly representative of the Australian population and all contain similar survey questions about attitudes to work and family roles. There are some exceptions. The 1986 Social Structure of Australia Project only sampled respondents in paid employment and the Negotiating the Life Course (NLC) survey (McDonald et al. 1999) restricted its sample to respondents between 18 and 54 years of age. For reasons of comparability, the analytical samples of the three remaining surveys have also been restricted to these criteria. The Households Income and Labour Dynamics in Australia (HILDA) survey conducted interviews with all members of the household aged over 15 years (Watson and Wooden 2002). As the other surveys do not, and to avoid possible nesting or contextual bias issues, we have randomly selected one member of each HILDA household to be included in our analysis. Finally, to account for bias in our analysis due to the considerable variation in sample sizes, each data file is weighted to an equal sample size in the combined analysis file. ${ }^{1}$ The combined dataset thus includes five time points covering the period 1986-2005.

\footnotetext{
1 This is achieved by using a standard weighting procedure: target sample size is derived by dividing the total number of cases for all samples by the number of samples. Sample-weights are then derived by dividing the target sample size by the actual sample size. Samples are then weighted by their respective sample-weights. Thus, both equal sample size and the correct degrees of freedom are achieved.
} 
We are aware that these variations in sample design pose some limitations for our analysis. Ideally it would be desirable to have identical sample designs for each data point. For example, it is possible that employed women in 1986 held less traditional gender attitudes than employed women in 2005. Thus any observed changes in women's attitudes over time may be due in part to selectivity bias reflecting the fact that as women's labour force participation rates increased over time, the sample of women in 2005 might include women with relatively more conservative gender attitudes compared to the sample in 1986. However, the absence of alternative datasets means that we are restricted to these datasets for our analysis. We also impose other exclusion restrictions based on age and employment to ensure comparability. Additionally we include a range of respondent characteristics in each of our regression models which may go some way toward controlling for variations in sample design. And finally, we note that our results are very similar to those obtained in cross-national studies in a number of different countries, suggesting that we can be reasonably, confident that our findings are not artefacts of these specific sample designs (Braun and Scott 2009).

\section{Variables}

We measure attitudes to gender roles using five items:

1. It is better for the family if the husband is the principal breadwinner outside the home and the wife has primary responsibility for the home and children.

2. If both husband and wife work, they should share equally in the housework and childcare.

3. Ideally, there should be as many women as men in important positions in government and business.

4. There should be satisfactory childcare facilities so that women can take jobs outside the home.

5. A woman who works in a paid job can be just as good a mother as one who does not.

Note that items 3 and 4 are not available in the HILDA survey. Additionally there are some minor variations in item wording and response categories across the surveys, but these are minor and unlikely to affect comparability. For example the HILDA item equivalent to item 1 above is worded: 'It is better for everyone involved if the man earns the money and the woman takes care of the home and children'. The HILDA item equivalent to item 2 above is worded: 'If both partners in a couple work, they should share equally in the housework and care of children'. And finally the HILDA item equivalent to item 5 above is worded: "A working mother can establish just as good a relationship with her children as a mother who does not work for pay'.

There is also variability across the surveys in the response categories for each item. Responses in HILDA were collected on a scale from 1 (strongly disagree) to 7 (strongly agree). In NLC, there were 5 response categories, with $1=$ strongly agree, 
$2=$ agree, $3=$ mixed feelings, $4=$ disagree, and $5=$ strongly disagree. In the Social Structure of Australia and Neoliberalism, Inequality and Politics in Australia surveys responses were collected on a 4-point scale with categories 1 (strongly agree), 2 (agree), 3 (disagree) and 4 (strongly disagree). For the regression analysis we standardize the scores by scaling responses to run from 0 to 1 , with responses rescaled when required so that for all items 0 indicates more liberal attitudes and 1 indicates a more conservative or traditional viewpoint. Potentially variation across the surveys in response categories may affect the comparability of responses, particularly since NLC and HILDA offered respondents a neutral response category. However, only $3 \%$ of NLC respondents chose the neutral response across each of the items. In the HILDA questionnaire only the first and last response options were labelled, and respondents were instructed to tick a box between 1 and 7. For item 1, $19 \%$ chose the middle box, $7 \%$ chose the middle box for item 2 and $18 \%$ chose the middle box for item 5 . While these variations in item responses are a limitation for our analysis, we are confident that they do not invalidate our comparisons. Overall, the items in the HILDA survey are the least comparable in terms of wording and response categories. However, even if we drop these data from our analysis, our broad conclusions do not change. Moreover, many previous studies have drawn reliable conclusions from comparative datasets that are not strictly comparable in design, data collection methods or wording of survey items, even when the datasets come from the same project, such as the International Social Survey Project (ISSP) (see Braun and Scott 2009).

We examine a number of independent variables suggested by earlier studies to influence beliefs about gender roles. We hypothesize two scenarios for change over time during the period under study. The first is a simple continuous change over time towards more progressive gender role attitudes; this would suggest a model in which a single linear trend describes changes in attitudes between 1985 and 2005. We hypothesize a second scenario in which change over the period is best described using two trends. Our reasoning for such a dual-trend model lies in evidence of a slowing or even reversal of the trend towards more egalitarian views. In Australia the emergence of more conservative views may be indicated by the electoral success of a conservative Federal government led by John Howard during this period, with its emphasis on a more traditional, family-oriented policy agenda and the consolidation of a long trend toward increasingly neoliberal economic policies (Brennan 2007; Western et al. 2007b). The prolonged support for the Coalition from the mid-1990s to their defeat in 2007 may suggest a slowing or reversal of progressive gender attitudes during this period. If these expectations are correct we would expect to find an initial trend towards more progressive attitudes from the mid-1980s to the mid-1990s, followed by a less progressive or even a conservative trend.

To assess this we include two variables for time, one covering the period from 1986 to 1995, and the other from 1995 onwards. The first is coded as the number of years since 1986. The second measure is an interaction variable coded as whether or not the survey was completed since 1995 by the number of years since 1995 . Note that this is similar to including a measure of time squared to see if the effect of time is curvilinear. With our approach, however, we are able to fix the point at which we 
expect to observe the change in attitude trends. ${ }^{2}$ We have fixed the turnover point at 1995, shortly before the election of the Howard government, arguing that if indeed his electoral success stems from a change in attitudes in the Australian electorate, such a change would be likely to develop before these elections.

We constructed four birth cohorts: respondents born before 1940, respondents born 1940-1959, respondents born 1960-1979 and respondents born since 1980. These groupings coincide with the pre-war generation, the first post-war generation, the generation socialized in the affluent 1960s and 1970s and the generation socialized during the 1980s and 1990s. We expect successive generations to show more progressive attitudes towards gender, with the possible exception of the youngest cohort. This youngest cohort was socialized largely during a period of conservative government in Australia led by Howard, leader of the conservative Liberal-National party coalition and Prime Minister of Australia from 1996 to 2007. The family-oriented conservative policy agenda of this government may have affected attitudes about gender leading to a slightly more conservative outlook for this generation (Brennan 2007). We include dummy indicators for each cohort, excluding the second cohort (born 1940-1959) as the control category.

We include dummy indicators to distinguish between single (never married), married, cohabiting, separated or divorced and widowed. Married is the reference category. We expect cohabiting respondents to hold more liberal attitudes to gender issues than married respondents. Other research has indicated that cohabiting couples are more liberal and more supportive of egalitarian gender roles (Smock 2000; Baxter 2005).

Children cause a great deal of change in a relationship, both in the character and often also in the distribution of daily household tasks (Baxter et al. 2008). In Australia, the arrival of children often leads to women's withdrawal or decreased involvement in the labour market. Such changes may influence gender attitudes. To test for this, we include a dummy variable indicating whether children under the age of 16 are living in the household (coded $1=$ yes). ${ }^{3}$

We expect higher education to be associated with more progressive gender attitudes. We include three dummy variables for those with incomplete secondary schooling (1), completed secondary education (2) and tertiary education (3). The reference category for the regression models is completed secondary education.

We include a measure of whether respondents are employed full-time, defined as 30 or more hours of paid employment per week, or part-time, defined as less than 30 hours of paid employment per week.

We also include a measure of whether the respondent's partner is employed. We expect individuals in households in which both partners are employed to be more progressive in their attitudes to gender compared to households in which only the male partner is employed.

\footnotetext{
${ }^{2}$ We also ran the analysis including a measure of time squared (results not shown) and found very similar results to those reported here.

3 Since these changes in attitudes are likely to endure after the children have moved out, information regarding whether the respondent ever had any children would have been preferable, but such information is not available. This may result in an underestimation of the effect of children in the household.
} 
We expect religion to be associated with more conservative gender attitudes. To examine this we include a dummy variable indicating whether respondents are religious (coded yes $=1$ ). This variable was based on a question asking whether respondents considered themselves to belong to a particular religious denomination. Additional analysis (not shown) showed no significant variations in gender attitudes across specific religious denominations.

Following earlier research we expect men to report more conservative gender attitudes than women. We therefore include gender as a dummy variable (coded $1=$ men). We test for changes in the gender gap over time by including an interaction between gender and each of our time variables. We also included gender interactions with other variables to examine differences between men and women in the determinants of attitude variation. Non-significant interactions were dropped from the final model. Comparisons in model quality were made on the basis of statistical significance of the trend estimates and fit of the model by comparing adjusted $R^{2}$, Akaike information criterion (AIC) and Bayesian information criterion (BIC) values. Our final regression model includes gender interactions with marital status and whether partner is employed. These were the only gender interactions which were statistically significant.

Table 1 reports means and standard deviations for all of the independent variables in the analyses separately by year of survey. We have not included the time variables in this table as these variables are only meaningful for the combined dataset.

Table 1 Means and standard deviations for independent variables

\begin{tabular}{|c|c|c|c|c|c|c|c|c|c|c|}
\hline \multirow[b]{3}{*}{ Born before 1940} & \multirow{2}{*}{\multicolumn{2}{|c|}{$\frac{1986}{\text { Mean SD }}$}} & \multirow{2}{*}{\multicolumn{2}{|c|}{$\frac{1993}{\text { Mean SD }}$}} & \multirow{2}{*}{\multicolumn{2}{|c|}{$\frac{1997}{\text { Mean SD }}$}} & \multirow{2}{*}{\multicolumn{2}{|c|}{$\frac{2001}{\text { Mean SD }}$}} & \multirow{2}{*}{\multicolumn{2}{|c|}{$\frac{2005}{\text { Mean SD }}$}} \\
\hline & & & & & & & & & & \\
\hline & 0.13 & 0.33 & 0.02 & 0.15 & - & - & - & - & - & - \\
\hline Born 1940-1959 & 0.65 & 0.48 & 0.62 & 0.49 & 0.51 & 0.50 & 0.37 & 0.48 & 0.35 & 0.48 \\
\hline Born 1960-1979 & 0.22 & 0.41 & 0.36 & 0.48 & 0.49 & 0.50 & 0.58 & 0.49 & 0.56 & 0.50 \\
\hline Born 1980 to present & - & - & - & - & - & - & 0.05 & 0.22 & 0.09 & 0.29 \\
\hline Married & 0.63 & 0.48 & 0.67 & 0.47 & 0.59 & 0.49 & 0.52 & 0.50 & 0.58 & 0.49 \\
\hline Cohabiting & 0.08 & 0.27 & 0.07 & 0.25 & 0.08 & 0.28 & 0.11 & 0.31 & 0.12 & 0.32 \\
\hline Single (never married) & 0.21 & 0.41 & 0.19 & 0.39 & 0.21 & 0.41 & 0.24 & 0.42 & 0.18 & 0.38 \\
\hline Divorced/separated & 0.05 & 0.22 & 0.06 & 0.24 & 0.12 & 0.32 & 0.13 & 0.34 & 0.12 & 0.33 \\
\hline Widowed & 0.03 & 0.16 & 0.01 & 0.10 & 0.01 & 0.09 & 0.01 & 0.08 & 0.01 & 0.09 \\
\hline Children & 0.54 & 0.50 & 0.70 & 0.46 & 0.66 & 0.47 & 0.63 & 0.48 & 0.53 & 0.50 \\
\hline Incomplete secondary education & 0.32 & 0.47 & 0.31 & 0.46 & 0.43 & 0.49 & 0.18 & 0.39 & 0.09 & 0.28 \\
\hline (Some) tertiary education & 0.34 & 0.47 & 0.26 & 0.44 & 0.14 & 0.34 & 0.38 & 0.49 & 0.62 & 0.49 \\
\hline Employed part time & 0.12 & 0.33 & 0.24 & 0.43 & 0.23 & 0.42 & 0.24 & 0.42 & 0.28 & 0.45 \\
\hline Employed partner & 0.46 & 0.50 & 0.67 & 0.47 & 0.54 & 0.50 & 0.52 & 0.50 & 0.59 & 0.49 \\
\hline Religious & 0.64 & 0.48 & 0.99 & 0.07 & 0.71 & 0.45 & 0.70 & 0.46 & 0.62 & 0.49 \\
\hline Gender $($ men $=1)$ & 0.55 & 0.50 & 0.44 & 0.50 & 0.46 & 0.50 & 0.49 & 0.50 & 0.42 & 0.49 \\
\hline$N$ & 944 & & 1,708 & & 1,483 & & 2,502 & & 699 & \\
\hline
\end{tabular}




\section{Results}

Table 2 shows the proportion of men and women who agree or strongly agree with each attitude item for each of the samples. Note that agreement on the first item (It is better for the family if the husband is the principal breadwinner and the wife has primary responsibility for the home and children) indicates a more conservative attitude to gender behaviour. For all of the other items agreement indicates a more liberal view. Consistent with other research, the results show that men consistently report more conservative views than women on all items. Overall there is evidence that both men and women are becoming more liberal in their views over time, although on some items there is little evidence of change, and for others there is an indication of more conservative views emerging in the early 2000s. The latter is the case for item 1 in particular where we see a much higher proportion of men and women supporting a traditional division of labour between husbands and wives in 2005 compared to 1997 and 2001. Interestingly the data here also show that women in the later surveys are less inclined to believe that a woman who works in a paid job can be just as a good a mother as one who does not work (item 5). The results for men also show a more conservative trend in beliefs over time, although it appears to reverse in the early 2000 s.

While these percentages enable some preliminary insight into trends over time, one problem with comparing raw percentages such as these is that we have not controlled for variation in sample composition. For example, if the samples differ in terms of the proportion of respondents with tertiary education or in different age cohorts, we may be observing variations in sample characteristics as opposed to trends over time in attitudes. To adjust for this, and to examine the effect of each of the independent variables on gender role attitudes, we run a set of ordinary least squares regression models predicting variation in each gender attitude item using all of the independent variables discussed above. The results of these models are presented in Table 3. For these models item 1 has been recoded so that for all measures of attitudes a lower score indicates a more egalitarian viewpoint.

We suggested two patterns of change over time, a single continuous trend towards more progressive attitudes towards gender behaviour; and an initial trend towards more progressive gender role attitudes followed by an attenuation of the progressive trend, or perhaps even a reversal, towards more conservative attitudes. To investigate these two possibilities we tested models including both a single and a dual time trend, and selected the best fitting model on the basis of parameter significance and overall model fit (using adjusted $R^{2}$ and AIC and BIC as criteria). In four of the five models we achieved a better fit if two time trends rather than one were included. Only attitude item 2 (If both husband and wife work they should share equally in the housework and childcare) showed a continuous trend toward more liberal attitudes over time and no change in trends in the mid-1990s. For all other issues, both the continuous time trend variable and the variable capturing a possible trend change in 1995 were significant.

For issues 1, 3 and 4, we observe similar trends over time. In all cases, there is evidence of a trend toward more liberal attitudes but only until 1995, when we observe either a stabilization of views or a reversal toward more conservative views. 


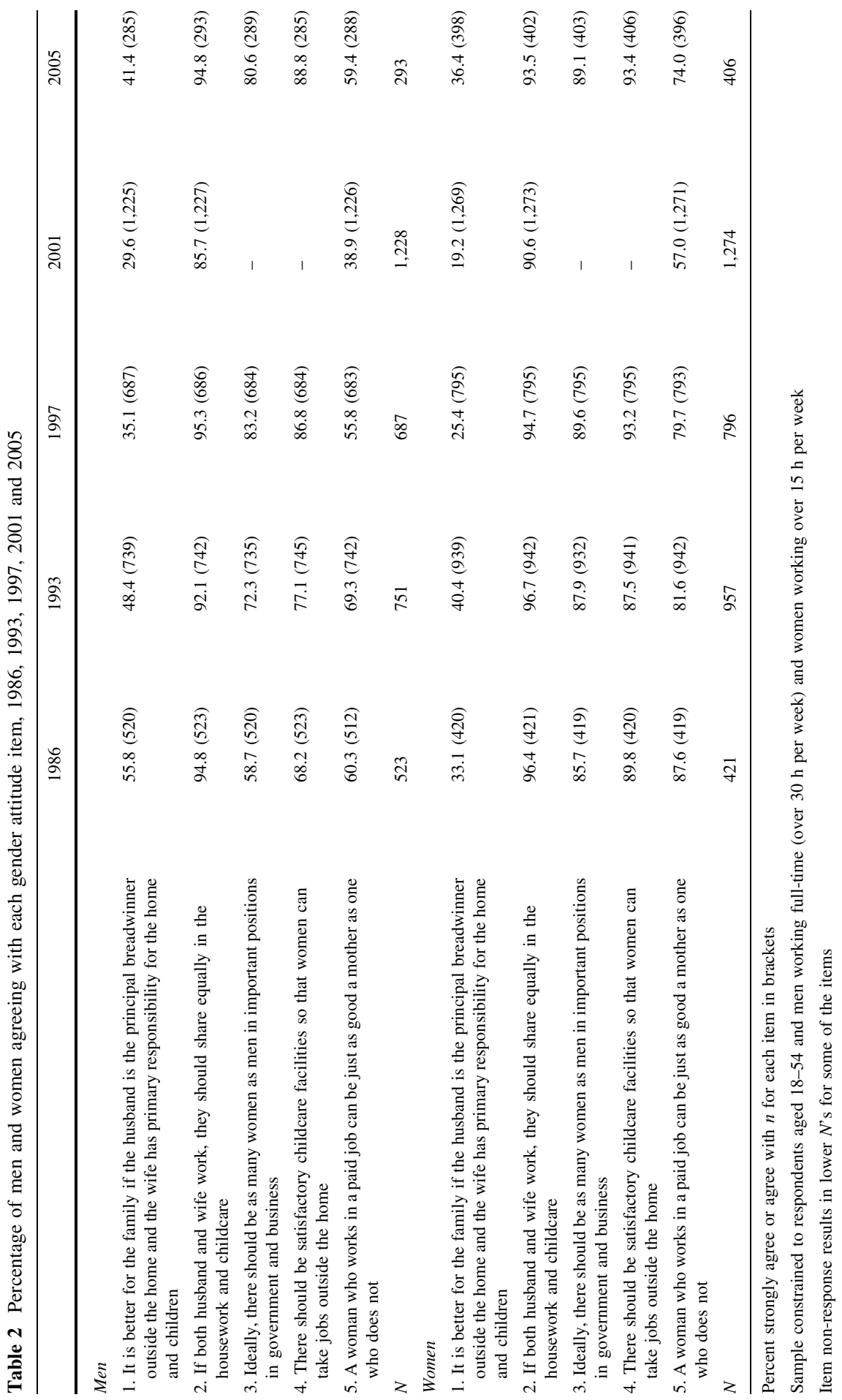




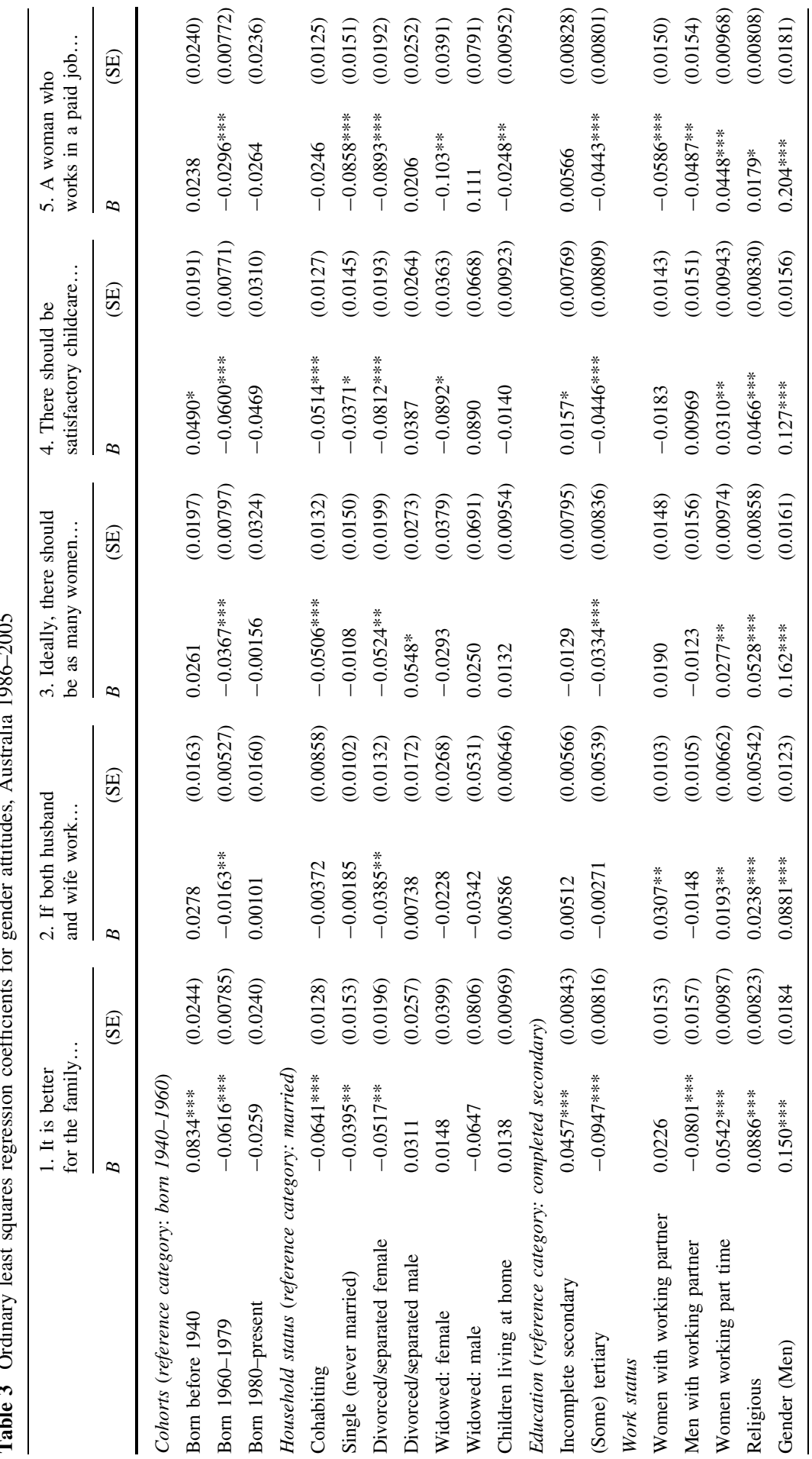




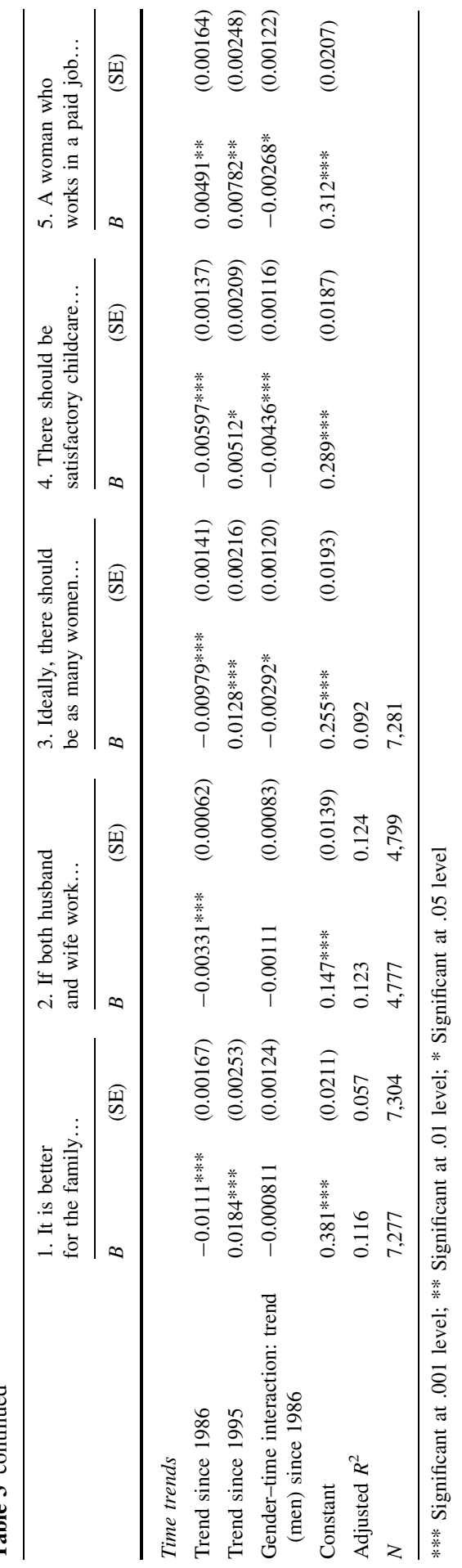


For issue 5 on the other hand, concerning combining paid work with good mothering, we observe a very different trend. In this case, the trend over time is toward more conservative views, with a further strengthening of this conservative trend in 1995. Hence, in line with other studies that indicate less support for change associated with the best parent to care for young children, these results indicate that Australians are more conservative about change in women's role as mothers than about change in women's involvement in paid employment.

These patterns are best illustrated by the graphs in Fig. 1 showing the predicted means for each item separately by gender controlling for all of the other variables in the regression models. Note that items 3 and 4 were not included in the 2001 survey and hence the graphs show predicted values obtained by interpolating the trend lines. The graphs illustrate the results discussed above, showing a trend toward more egalitarian attitudes on items 1, 3 and 4 until the mid-1990s, followed by the reversal or stabilization of views. For item 2 we see a continuous trend toward more
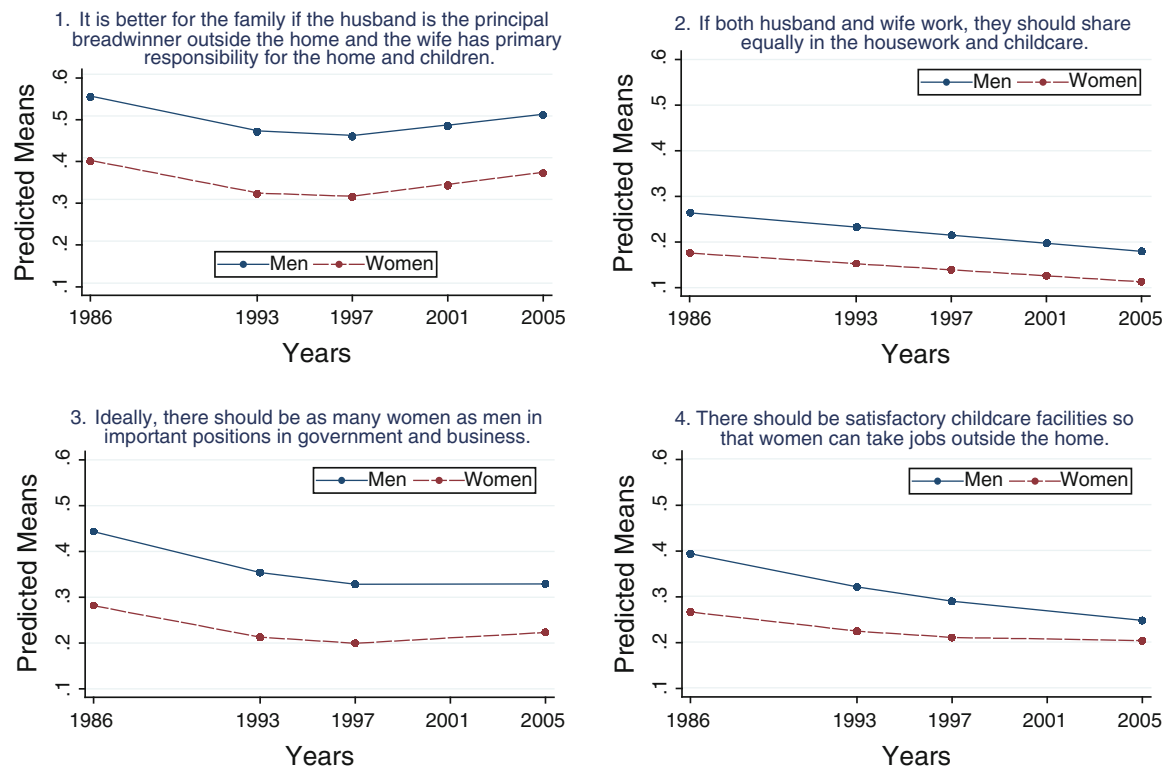

5. A woman who works in a paid job can be just as

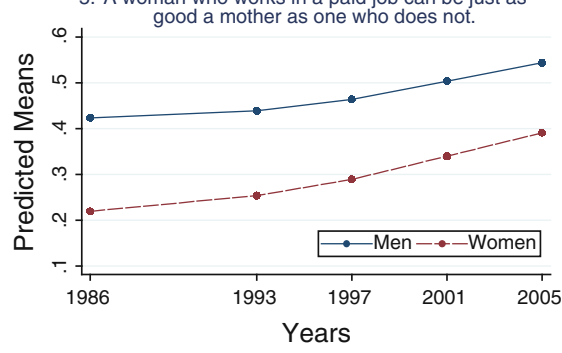

Fig. 1 Predicted means on gender attitude items by gender and year 
liberal views while for item 5 the results show a trend toward more conservative views.

Similarly to previous studies, we find that men are consistently more conservative than women in their gender attitudes. Although the size of the gender effect varies between issues, for all of the issues we examine the influence of gender is typically the single largest determining factor in the model. To investigate whether this difference is stable over time, we included gender interactions for the time trends in our model. The results show that for items 3, 4 and 5 men's attitudes are moving closer to women's attitudes. Given that men started out more conservative than women, this means they are catching up with women over time. The interaction terms are not sufficiently large for men to actually overtake women and men therefore remain more conservative than women for all issues, at all time points.

To what degree are the trends over time mirrored by cohort effects? We expected the younger cohorts to be more progressive than older cohorts. This is largely borne out by the findings, especially for the three oldest cohorts. The oldest cohort, born before 1940, is the most conservative, and when compared to the control category (those born from 1940 to 1959), this difference is statistically significant for items 1 and 4. The 1960-1979 cohort reports significantly more progressive views than the control group on all issues. Interestingly, it is this cohort that reports the most progressive views on most of the attitude items, while the youngest cohort, born after 1980, hold views comparable to the second oldest cohort (the control category). This further supports our finding of a conservative shift in gender attitudes in Australia. However, more probably the lack of statistically significant findings for the youngest cohort is caused by group size effects, with this group substantially smaller than the older cohorts, and absent from our first three surveys.

In line with previous research, a number of the other variables in our models significantly affect gender attitudes. Single and cohabiting people tend to report more liberal attitudes than married people. To some degree these findings may be influenced by a potential age effect, as a number of cohabiting respondents are likely to be young and cohabiting only before an intended marriage, and single people will generally be younger than married people. However, the models control for birth cohort, indicating that these effects are independent of age.

Interestingly the analysis shows that divorce and separation have different consequences for men and women in their attitudes towards gender behaviour. The gender interaction for this variable shows that women who are divorced are consistently more progressive than married women, with the difference statistically significant for all issues. Indeed, divorced or separated women often hold the most egalitarian views compared to women in other relationship types. It may be that the process of separation and divorce affects women's attitudes, or alternatively women with more liberal attitudes may be more likely to separate and divorce. Widowhood shows a comparable gender difference, although the pattern is less consistent: the small group size is likely to play a role here. However, while the estimates suggest that divorced or separated men are more conservative than married men, the difference is never statistically significant. 
We find that those with higher levels of education hold more egalitarian gender attitudes. Tertiary educated respondents hold significantly more progressive views on most of these issues than the control category of secondary educated respondents. Respondents with incomplete secondary education tend to be more conservative on gender issues than those with completed secondary education. In line with expectations, we find that respondents who report a religious denomination are consistently more conservative on all five items.

Finally, in relation to employment status we find that women employed part-time are significantly more conservative on all issues than women employed full-time. With regard to working partners, the picture is less clear-cut. Men with employed partners tend to be significantly more progressive on items 1 and 5. Interestingly, women with employed partners hold more conservative views about the need to share household work than women whose partners are not employed (item 2); but perhaps the small number of women in the samples with partners not in employment may account for this. On the other hand, having a partner in employment is associated with more liberal attitudes for women about combining employment with mothering (item 5), as it is for men.

\section{Discussion}

Australia, like many other Western countries, has experienced substantial change in the patterning of work and family life since the 1960s. One of the biggest changes has been the increased involvement of married women with young children in paid employment, leading to a decline in the numbers of traditional male-breadwinner families in favour of a dual-earner model, although one in which women are usually employed part-time and men are typically employed full-time. This 'new traditional family', as it has been termed, has now replaced the male-breadwinner family as the dominant family type in Australia (De Vaus 2004; Australian Bureau of Statistics 2008). In addition, we have also seen increasing change in the demography of family life including the rise of cohabitation, the decline of marriage, increasing divorce and declining fertility (Australian Bureau of Statistics 2008). All of these trends, in combination with a variety of legislative changes designed to implement equality of opportunity by gender, have coincided with substantial shifts in attitudes about work and family roles. Our results show that on most of the issues examined here, Australian men and women have become increasingly more egalitarian in their views about gender arrangements. But the story is not so straightforward. The trends have taken a different direction since the mid-1990s. At this point we see a stabilization, or in some cases a reversal of trends. Over the last 10 years attitudes to gender arrangements have shifted and the trend toward liberalization has slowed markedly and possibly stalled.

Why has this happened? Some clues are to be found in studies of international trends in gender role attitudes. Our results are very similar to those reported by Braun and Scott (2009) based on ISSP data for several European countries and the United States. They report a trend toward greater egalitarianism in all countries from 1988 onward, followed by a retreat or levelling off since the 1990s, 
particularly in the United States and Britain, Additionally, they also find much greater variation in attitudes about the consequences of female labour force participation for the care of young children than in attitudes about women's involvement in the labour force. One explanation they reject is that attitude change has reached a ceiling after which population attitudes stabilize or retreat. Patterns in the Scandinavian countries do not support this as gender attitudes in these countries continue toward egalitarianism. Another possibility is that the difficulties of women combining paid work with care of young children, in the absence of state and labour market policies that support a reasonable work-life balance, mean that some people who might otherwise be supportive of increasing gender equality have given up on the view that this is possible. This explanation is plausible for Australia where the main strategy to combine paid and unpaid work has been for women to move into part-time employment in order to continue to undertake the bulk of unpaid work and childcare. But much research has shown that the time pressures faced by dual-earner families is considerable, even when women are employed part-time (Craig 2007; Rose et al. 2010). These pressures may lead some men and women to rethink how best to manage work and family responsibilities.

If we turn specifically to the timing of change in gender role attitudes in Australia, we can see that they may be linked to broader structural changes in gender equality in the labour market and political sphere. Many of the economic, demographic and social changes associated with women's increased entry into paid employment took place between the early 1970s and early 1990s. Arguably it was during this period that the second wave feminist movement was at its peak in Australia and the feminist agenda was most active in lobbying for equality of opportunity. It was during this period that the Women's Electoral Lobby was established (1972) and the Women's Liberation Movement was most visible (Lake 1999). Unlike feminists in other countries such as the United States, where the women's liberation movement tended to operate most successfully as a lobby group independent of government, in Australia feminists were successful in operating within the state and had some success, particularly during the early 1970s, in influencing the agenda of the Federal government (Eisenstein 1996). For example, Gough Whitlam, Prime Minister of Australia and leader of the Federal Labor party from 1972 to 1975, appointed a high-profile feminist academic, Elizabeth Reid, as his advisor on women's affairs in 1971 (Lake 1999). Reid was the first in a long list of high-profile 'femocrats' who headed various women's units, women's affairs centres and equal employment opportunity units established within the Australian Public Service to monitor and lobby for women's issues including childcare funding, funding for women's health centres, crisis refuges and equality in the workforce and political sphere.

Since the mid-1990s however, feminist lobby groups have gradually lost momentum, and the fight for equality of opportunity has become less visible. Australia has until recently been led by a conservative Federal government that introduced and consolidated a number of neoliberal social policies in support of a male-breadwinner model of family life. There is also increasing debate and media commentary about the 'failure' of feminism and the post-feminist agenda of 'generation X and Y' (Dux and Simic 2008). A number of popular commentaries 
have appeared extolling the virtues of motherhood (Manne 2005) and cautioning women against delaying childbearing to the point where biology makes it no longer possible to conceive children naturally (Hewlett 2002). While these developments may not be sufficient to warrant the term 'backlash', they nevertheless indicate a degree of questioning of some of the central tenets underlying the earlier feminist movement for equality of opportunity. It is possible that the slowdown in liberalization of attitudes to work and family arrangements indicated by our results is a reflection of these broader trends towards a degree of ambivalence and a greater questioning of the goals of the earlier women's liberation movement.

At the same time, our results indicate increasing conservatism throughout the last 20 years on attitudes toward combining paid work and mothering. In contrast to views about who should be the main breadwinner, whether men and women should share housework and childcare and whether women should be given opportunities to participate fully in employment and government, Australians since the mid-1980s have become more conservative in their views about whether women in paid work can be good mothers. This is in line with other research both in Australia (Evans and Kelley 2002) and overseas (Kane and Sanchez 1994; Scott 2008) that indicates greater acceptance of women's involvement in the paid labour force compared to changes in gender roles in the family. It appears that Australians hold quite contradictory views about women's roles. On the one hand, they are supportive of women's greater access to work outside the home, but only if this work does not interfere with their primary responsibility as mothers. This may go some way toward explaining why women increasingly delay childbearing and some forgo childbearing altogether. If women, like men, support a traditional arrangement whereby good mothering involves full-time care of children, then it is difficult to reconcile this view with paid employment. Further, research has shown that both men and women in Australia have increased their time spent caring for children over recent years, with women employed full-time spending as much time with their children as women who are not employed (Craig 2007). Cross-national research also reports increases in men's and women's time on childcare in a number of countries (Gauthier et al. 2004; Sayer et al. 2004). It appears that women prioritize mothering to the point where they are willing to give up other activities such as leisure and sleep in order to make the necessary adjustments required to spend as much quality time with children as mothers not in employment (Craig 2007).

As in many other studies we find that men are consistently more conservative than women on all of the issues examined here. This is perhaps not surprising, as some might argue that men have more to lose than women from changing gender arrangements. But there is also evidence of some convergence of views with men moving closer to women's views on some of the issues. This contrasts with US research that tends to find that women's attitudes have undergone a faster pace of change than those of men, who typically lag behind in levels of support for gender equality.

Finally there is evidence that both cohort differences and differences in social characteristics affect gender attitudes. The oldest cohort, that is those born before 1940, are clearly the most conservative on all of the issues examined here. But it is interesting that the 1960-1979 cohort report some of the most liberal views. Perhaps this is the result of growing up at a time when the second wave women's liberation 
movement was at its peak in Australia and changes in policy and cultural practices were visible. But cohort differences are not the full explanation: other factors such as level of education and marital status are also important, suggesting that lifecourse events and experiences also shape gender attitudes.

Overall our results indicate that the trend toward more liberal attitudes about gender has stalled in Australia and in some cases, reversed. Although women have made enormous gains in obtaining access to paid employment and there is increasing support for a shared division of labour at home when both partners are in paid employment, there is less support than in the past for family arrangements that diverge from the male-breadwinner model and increasingly less support for combining motherhood with paid employment. In some ways these trends are not surprising. In comparison to other OECD countries, Australia has embraced the new traditional model of family life with women overwhelmingly employed part-time rather than full-time when there are young children in the household. The attitude trends reported here reflect the fact that women's movement into paid employment has been accepted largely because it has not challenged traditional divisions of labour and has continued to be supported only insofar as it does not alter gendered divisions of labour in the home.

Acknowledgments This research makes use of data collected with funding from the Australian Research Council Discovery project scheme (\#DP DP0449516). It also uses unit record data from the Households, Income and Labour Dynamics in Australia (HILDA) survey. The HILDA survey was initiated, and funded, by the Australian Federal Department of Families, Housing, Community Services and Indigenous Affairs and is managed by the Melbourne Institute of Applied Economic and Social Research at the University of Melbourne. We are grateful for the comments from two anonymous reviewers. The findings and views reported in this paper are those of the authors and should not be attributed to any of these organizations or individuals.

Open Access This article is distributed under the terms of the Creative Commons Attribution Noncommercial License which permits any noncommercial use, distribution, and reproduction in any medium, provided the original author(s) and source are credited.

\section{Appendix}

See Table 4.

Table 4 Details of cross-sectional national surveys providing comparable data on attitudes to gender roles in Australia, 1986-2005

\begin{tabular}{|c|c|c|c|c|c|}
\hline Year & Title & $\begin{array}{l}\text { Sample parameters in } \\
\text { original design }\end{array}$ & $\begin{array}{l}\text { Method of data } \\
\text { collection }\end{array}$ & $\begin{array}{l}\text { Total sample } \\
\text { size }\end{array}$ & $\begin{array}{l}\text { Analytical } \\
\text { sample } \\
\text { size }\end{array}$ \\
\hline 1986 & $\begin{array}{l}\text { Social structure of } \\
\text { Australia }^{\mathrm{a}}\end{array}$ & $\begin{array}{l}\text { National random sample } \\
\text { of employed men and } \\
\text { women (men at least } \\
30+\mathrm{h} \text { per week) }\end{array}$ & $\begin{array}{r}\text { Face-to-face } \\
\text { interviews }\end{array}$ & 1,195 & 944 \\
\hline 1993 & $\begin{array}{l}\text { Social structure of } \\
\text { Australia }^{\mathrm{b}}\end{array}$ & $\begin{array}{l}\text { National random sample } \\
\text { of men and women }\end{array}$ & $\begin{array}{l}\text { Self complete } \\
\text { mail-out } \\
\text { questionnaire }\end{array}$ & 2,780 & 1,708 \\
\hline
\end{tabular}


Table 4 continued

\begin{tabular}{|c|c|c|c|c|c|}
\hline Year & Title & $\begin{array}{l}\text { Sample parameters in } \\
\text { original design }\end{array}$ & $\begin{array}{l}\text { Method of data } \\
\text { collection }\end{array}$ & $\begin{array}{l}\text { Total sample } \\
\text { size }\end{array}$ & $\begin{array}{l}\text { Analytical } \\
\text { sample } \\
\text { size }\end{array}$ \\
\hline 1996-1997 & $\begin{array}{l}\text { Negotiating the } \\
\text { lifecourse, } \\
\text { Wave } 1^{\mathrm{c}}\end{array}$ & $\begin{array}{l}\text { National random sample } \\
\text { of men and women } \\
\text { aged } 18-54 \text { years }\end{array}$ & $\begin{array}{l}\text { Computer } \\
\text { assisted } \\
\text { telephone } \\
\text { interviews }\end{array}$ & 2,231 & 1,483 \\
\hline 2001 & $\begin{array}{l}\text { Households, } \\
\text { income and } \\
\text { labour dynamics } \\
\text { in Australia, } \\
\text { Wave } 1^{\mathrm{d}}\end{array}$ & $\begin{array}{l}\text { National random sample } \\
\text { of households }\end{array}$ & $\begin{array}{l}\text { Face-to-face } \\
\text { interviews } \\
\text { and self } \\
\text { complete } \\
\text { questionnaire }\end{array}$ & $\begin{array}{l}7,682 \\
\text { households; } \\
13,969 \\
\text { individuals }\end{array}$ & 2,502 \\
\hline 2005 & $\begin{array}{l}\text { Neoliberalism, } \\
\text { inequality and } \\
\text { politics in } \\
\text { Australia }^{\mathrm{e}}\end{array}$ & $\begin{array}{l}\text { National random sample } \\
\text { of men and women }\end{array}$ & $\begin{array}{l}\text { Computer } \\
\text { assisted } \\
\text { telephone } \\
\text { interviews }\end{array}$ & 1,623 & 699 \\
\hline
\end{tabular}

\footnotetext{
a Western et al. (1986)

b Western et al. (1993)

c McDonald et al. (1999)

d HILDA, Waves 1-6, Release 6.0. (FaHCSIA)

e Western et al. (2005)
}

\section{References}

Amato, P. R., \& Booth, A. (1991). Consequences of parental divorce and marital unhappiness for adult well-being. Social Forces, 69(3), 895-914.

Australian Bureau of Statistics. (2008). Australian social trends. Cat. No. 4102.0. Canberra.

Baxter, J. (2002). Patterns of change and stability in the gender division of household labour in Australia, 1986-1997. Journal of Sociology, 38(4), 399-424.

Baxter, J. (2005). To marry or not to marry: Marital status and the household division of labour. Journal of Family Issues, 26(3), 300-321.

Baxter, J., Hewitt, B., \& Haynes, M. (2008). Life course transitions and housework: Marriage, parenthood and time on housework. Journal of Marriage and Family, 70(May), 259-272.

Bittman, M., England, P., Sayer, L., Folbre, N., \& Matheson, G. (2003). When does gender trump money? Bargaining and time in household work. American Journal of Sociology, 109, 186-214.

Blunsdon, B., \& Reed, K. (2005). Changes in attitudes to mothers working: Evidence from Australian surveys. Labour \& Industry, 16(2), 15-27.

Braun, M., \& Scott, J. (2009). Changing public views of gender roles in seven nations, 1988-2002. In M. Haller, R. Jowell, \& T. W. Smith (Eds.), The international social survey programme 1984-2009: Charting the globe (pp. 358-377). Oxford: Routledge.

Brennan, D. (2007). Babies, budgets, and birthrates: Work/family policy in Australia 1996-2006. Social Politics, International Studies in Gender, State \& Society, 14(1), 31-57.

Brewster, K. L., \& Padavic, I. (2000). Change in gender-ideology, 1977-1996: The contributions of intracohort change and population turnover. Journal of Marriage and Family, 62(2), 477-487.

Brooks, C., \& Bolzendahl, C. (2004). The transformation of US gender role attitudes: Cohort replacement, social-structural change, and ideological learning. Social Science Research, 33(1), $106-133$.

Campbell, I., Whitehouse, G., \& Baxter, J. (2009). Australia. Casual employment, part-time employment and the resilience of the male-breadwinner model. In L. F. Vosko, M. Macdonald, \& I. Campbell (Eds.), Gender and the contours of precarious employment (pp. 60-75). Abingdon: Routledge. 
Ciabattari, T. (2001). Changes in men's conservative gender ideologies, cohort and period influences. Gender and Society, 15(4), 574-591.

Craig, L. (2007). Contemporary motherhood: The impact of children on adult time. Aldershot: Ashgate.

Davis, N. J., \& Robinson, R. V. (1991). Men's and women's consciousness of gender inequality, Austria, West Germany, Great Britain, and the United States. American Sociological Review, 56(1), $72-84$.

De Vaus, D. (2004). Diversity and change in Australian families. Statistical profiles. Melbourne: Australian Institute of Family Studies.

Dux, M., \& Simic, Z. (2008). The great feminist denial. Melbourne: Melbourne University Press.

Eisenstein, H. (1996). Inside agitators, Australian femocrats and the state. Sydney: Allen and Unwin.

Evans, M. D. R., \& Kelley, J. (2002). Attitudes towards childcare in Australia. The Australian Economic Review, 35(2), 188-196.

Faludi, S. (1992). Backlash: The undeclared war against women. London: Chatto and Windus.

Gauthier, A., Smeeding, T., \& Furstenberg, F. (2004). Are parents investing less time in children? Trends in selected industrialized countries. Population and Development Review, 30, 647-671.

Hewlett, S. (2002). Creating a life, what every woman needs to know about having a baby and a career. New York: Miramax.

Holtz, G. T. (1995). Welcome to the jungle, the why behind 'Generation X'. New York: St. Martin's Press.

Inglehart, R., \& Norris, P. (2003). Rising tide: Gender equality and cultural change around the world. Cambridge: Cambridge University Press.

Kane, E. W. (1995). Education and beliefs about gender inequality. Social Problems, 42(1), 74-90.

Kane, E. W., \& Sanchez, L. (1994). Family status and criticism of gender inequality at home and at work. Social Forces, 72(4), 1079-1102.

Lake, M. (1999). Getting equal. The history of Australian feminism. Sydney: Allen and Unwin.

Manne, A. (2005). Motherhood, how should we care for our children?. Sydney: Allen and Unwin.

Mason, K. O., \& Lu, Y. H. (1988). Attitudes toward women's familial roles, changes in the United States, 1977-1985. Gender and Society, 2(1), 39-57.

McDonald, P., Jones, F., Mitchell, D., \& Baxter, J. (1999). Negotiating the life course, Wave 11997 [computer file]. Canberra: Australian Social Science Data Archive, The Australian National University.

Mitchell, D. (2005). Making families work. In S. Wilson, G. Meagher, R. Gibson, D. Denemark, \& M. Western (Eds.), Australian social attitudes: The first report (pp. 30-41). Sydney: UNSW Press.

Morgan, S. P., \& Waite, L. J. (1987). Parenthood and the attitudes of young adults. American Sociological Review, 52(4), 541-547.

Organisation for Economic Co-operation and Development (OECD). (2009). Society at a glance 2009OECD social indicators. Available from www.oecd.org/els/social/indicators/SAG. Accessed 22 April 2010.

Rose, J., Baxter, J., \& Hewitt, B. (2010). Time to balance: do gender, context and employment hours affect satisfaction with time pressure? Paper presented at 11th Australian Institute of Family Studies Conference, Melbourne, 7-9 July.

Sayer, L., Gauthier, A., \& Furstenberg, F. (2004). Educational differences in parents' time with children: Cross-national variations. Journal of Marriage and Family, 66, 1152-1169.

Scott, J. (2008). Changing gender role attitudes. In J. Scott, S. Dex, \& H. Joshi (Eds.), Women and employment: Changing lives and new challenges (pp. 156-178). Cheltenham: Edward Elgar.

Scott, J., Alwin, D. F., \& Braun, M. (1996). Generational changes in gender-role attitudes, Britain in a cross-national perspective. Sociology, 30(3), 471-492.

Smock, P. (2000). Cohabitation in the United States: An appraisal of research themes, findings, and implications. Annual Reviews Sociology, 26, 1-20.

Thornton, A., Alwin, D. F., \& Camburn, D. (1983). Causes and consequences of sex-role attitudes and attitude change. American Sociological Review, 48(2), 211-227.

Thornton, A., \& Young-DeMarco, L. (2001). Four decades of trends in attitudes toward Family issues in the United States: The 1960s through the 1990s. Journal of Marriage and the Family, 63(4), 1009-1037.

Van Gellecum, Y., Western, M., \& Baxter, J. (2008). Neoliberalism, gender inequality and the Australian labour market. Journal of Sociology, 44(1), 45-63.

Watson, N., \& Wooden, M. (2002). The Household, Income and Labour Dynamics in Australia (HILDA) Survey, Wave 1 survey methodology. HILDA project technical paper series, NO. 1/02, May 2002. 
Western, M., Baxter, J., \& Chesters, J. (2007a). How are families managing? In D. Denemark, G. Meagher, S. Wilson, M. Western, \& T. Phillips (Eds.), Australian social attitudes 2. Citizenship, work and aspirations (pp. 241-261). Sydney: UNSW Press.

Western, M., Baxter, J., Pakulski, J., Tranter, B., Western, J., \& Van Egmond, M. (2005). Neoliberalism, inequality and politics national survey. Data file. Brisbane: The University of Queensland Social Research Centre.

Western, M., Baxter, J., Pakulski, J., et al. (2007b). Neoliberalism, inequality and politics, the changing face of Australia. Australian Journal of Social Issues, 42, 401-408.

Western, J. S., Boreham, P. R., Clegg, S., Emmison, J. M., \& Marks, G. N. (1986). Social structure of Australia project, 1986. Canberra: Australian Social Science Data Archive.

Western, J. S., Emmison, J. M., Baxter, J., \& Chant, D. (1993). Social structure of Australia project, 1993. St. Lucia: Data file held by School of Social Science, University of Queensland. 